\title{
DIRGLIOSIOS ŽARNOS SINDROMAS: RIZIKOS VEIKSNIAI
}

\author{
Agnè Norbutaitė \\ Vilniaus universiteto Medicinos fakultetas
}

\author{
Raktažodžiai: dirgliosios žarnos sindromas, DŽS, rizikos \\ veiksniai.
}

\section{Santrauka}

Dirgliosios žarnos sindromas (DŽS) yra funkcinis žarnyno motorikos sutrikimas, kuriam būdingas lètinis pasikartojantis pilvo skausmas, diskomfortas ir pakitęs tuštinimasis, nesant kitų organinių virškinimo sistemos ligų. Prieš pradedant DŽS gydymą, reikia ịvertinti, kokie yra pagrindiniai simptomai, koks jų sunkumas ir dažnumas. Tyrimo tikslas - išanalizuoti ir apibendrinti mokslinès literatūros duomenis apie dirgliosios žarnos sindromo rizikos veiksnius, kurie turi itakos simptomų atsiradimui. Atlikta mokslinių publikacijų apžvalga, atranka ir analizè. Literatūros šaltinių paieška atlikta Medline $(\mathrm{Pu}-$ bMed), Google Scholar ir Medscape duomenų bazèse. I apžvalgą ịtrauktos 2016-2021 metų mokslinès publikacijos anglų kalba. Atrinkti, išanalizuoti ir apibendrinti 7 viso teksto straipsniai.

Tyrimo rezultatai atskleide, kad DŽS formavimuisi įtakos turi vidinių ir išorinių veiksnių sąveika. Klinikinejje praktikoje šio sindromo diagnozè nustatoma remiantis paciento anamneze ir būdingų simptomu pasireiškimu. Nustatyta genetinių veiksnių, ūminių enterinių infekcijų, kai kurių mitybos ịpročių, pakitusios žarnyno mikrobiotos įtaka. Ypač didelis DŽS paplitimas, siekiantis net 46 proc., nustatytas pacientams, turejusiems Giardia lamblia infekciją. Pastebetas ryšys ir su kitomis virškinamojo trakto infekcijomis, sukeltomis Campylobacter jejuni, Escherichia coli, Salmonella enterica, Clostridioides difficile ir Vibrio cholerae bakterijų.

Išvados. Pagrindiniai DŽS rizikos veiksniai yra moteriškoji lytis, jaunas amžius, genetinè predispozicija, mitybos ipročiai, persirgti gastroenteritai ir pakitusi mikrobiota. Stresas, nerimas ir depresija taip pat yra DŽS rizikos veiksniai, bet jie gali būti ir šio sindromo pasekmè.

\section{İvadas}

Dirgliosios žarnos sindromas (DŽS) yra funkcinis žarnyno motorikos sutrikimas, kuriam būdingas lètinis pasikar- tojantis pilvo skausmas, diskomfortas ir pakitęs tuštinimasis, nesant kitų organinių virškinimo sistemos ligų. Šio sindromo priežastys nèra visiškai aiškios, tačiau manoma, kad jo etiologija priklauso nuo įvairių veiksnių tarpusavio sąveikos [1]. DŽS yra dažniausia funkcinè virškinimo sistemos liga, turinti didelę įtaką gyvenimo kokybei. Paplitimas pasaulyje siekia daugiau nei 10 proc. populiacijos [2]. DŽS dažniau pasireiškia jaunesniems žmonems, moterims jis nustatomas du kartus dažniau, nei vyrams [3]. Klinikinejje praktikoje šio sindromo diagnozè nustatoma remiantis paciento anamneze ir būdingų simptomų pasireiškimu. Laboratoriniai ir instrumentiniai tyrimai atliekami norint įsitikinti, kad nèra kitų organinių ligų, kurios gali sukelti panašius simptomus, pavyzdžiui, uždegiminès žarnų ligos ar celiakijos [2]. Prieš pradedant DŽS gydymą, reikia ịvertinti, kokie yra pagrindiniai simptomai, koks jų sunkumas ir kaip dažnai jie pasireiškia. Jei simptomai lengvi, užtenka mitybos ir gyvenimo būdo pokyčių [1]. Pacientams, kurių simptomai sunkūs, gali būti skiriamas medikamentinis gydymas, rekomenduojama psichoterapija [4].

Tyrimo tikslas - išanalizuoti ir apžvelgti naujausią, įrodymais pagrịstą informaciją apie dirgliosios žarnos sindromo rizikos veiksnius.

\section{Tyrimo medžiaga ir metodai}

Atlikta mokslinių publikacijų apžvalga, atranka ir analizè. Literatūros šaltinių paieška buvo vykdoma kompiuterinèse bibliografinèse medicinos duomenų bazèse Medline (PubMed), Google Scholar ir Medscape. Paieškai naudoti raktiniai žodžiai ir jų deriniai: irritable bowel syndrome, IBS, risk factors. İ apžvalgą įtrauktos 2016-2021 metų mokslinès publikacijos anglų kalba. Atrinkti, išanalizuoti ir apibendrinti 7 viso teksto straipsniai.

\section{Tyrimo rezultatai}

Rizikos veiksniai. DŽS patogenezè yra sudètinga ir galutinai neišaiškinta, tačiau dauguma mokslininkų sutaria, kad DŽS atsiradimui įtakos turi ịvairūs vidiniai ir išoriniai veiksniai, kurių tarpusavio sąveika sukelia simptomų pasi- 
reiškimą [3]. Vieni iš dažniausiai minimų rizikos veiksnių yra moteriškoji lytis ir jaunas amžius (didesnis paplitimas tarp žmonių iki 50 metų) [4,5]. Atlikti ịvairūs tyrimai, kuriuose nustatyta ir genetinių veiksnių įtaka šiam sindromui, kadangi net trečdalio pacientų yra teigiama šeiminè anamnezė [3]. Neretai kaip svarbus rizikos veiksnys minimi ir tam tikri mitybos ịpročiai. Pastebėta, kad simptomų pasireiškimą daugeliui pacientų sukelia gausus cukraus, riebalų ir gliuteno turinčių produktų vartojimas $[3,6]$. Nustatyta, kad ūminès enterinès infekcijos yra vienas iš rizikos veiksnių, skatinančiuc DŽS išsivystymą. Tai patvirtina klinikiniai tyrimai su pelèmis, kuriuose pastebèta, kad žarnyno uždegimo sunkumas koreliuoja su vèliau po uždegimo atsiradusiu padidèjusiu visceraliniu jautrumu, o šis dalyvauja DŽS patogenezès mechanizmuose [2].

Su praeityje buvusiais gastroenteritais susijęs DŽS kartais literatūroje dar vadinamas poinfekciniu DŽS. Viename atliktame tyrime ypač didelis DŽS paplitimas, siekiantis net 46 proc., nustatytas pacientams, turejusiems Giardia lamblia infekciją [3]. Pastebėtas ryšys ir su kitomis praeityje buvusiomis virškinamojo trakto infekcijomis, kurias sukèlè tokios bakterijos kaip Campylobacter jejuni, Escherichia coli, Salmonella enterica, Clostridioides difficile ir Vibrio cholerae [6]. Tarp rizikos veiksnių dažnai minima ir pakitusi žarnyno mikrobiota. Tyrimuose nustatyta, kad pacientų, sergančių DŽS, žarnyno bakterijų ịvairovè yra mažesnè, lyginant su sveikais žmonėmis. Tarp turinčių DŽS pastebetas mažesnis laktobacilu ir bifidobakterijų kiekis [3]. Mikrobiota turi įtakos žarnų sienelès praeinamumui ir žarnyno judrumui, todèl ịvairūs jos pokyčiai gali padidinti DŽS riziką [7].

Dar vienas nenuginčijamas DŽS rizikos veiksnys yra patiriamas stresas, nerimas ar depresija. Šie sutrikimai turi itakos ne tik DŽS atsiradimui, bet ir simptomų sunkumui. Pastebèta, kad pacientams, patyrusiems daugiau traumuojančių gyvenimo įvykių (darbo praradimas, santykių nutrūkimas ir kt.), nustatomi sunkesni DŽS simptomai $[1,6]$. Vienos atliktos metaanalizès rezultatai parodè, kad nerimo simptomų paplitimas tarp DŽS pacientų siekia 39 proc., o depresijos -29 procentus. Psichologiniai sutrikimai yra ne tik rizikos veiksnys DŽS simptomų atsiradimui, bet gali būti ir DŽS pasekmè, kadangi šis sindromas reikšmingai veikia pacientų psichologinę būklę ir gyvenimo kokybę [6].

\section{Išvados}

1. Dirgliosios žarnos sindromo atsiradimui įtakos turi ịvairių vidinių ir išorinių veiksnių sąveika.

2. Pagrindiniai dirgliosios žarnos sindromo rizikos veiksniai yra moteriškoji lytis, jaunas amžius, genetinė predispozicija, mitybos ịpročiai, persirgti gastroenteritai ir pakitusi mikrobiota.
3. Stresas, nerimas ir depresija yra dirgliosios žarnos sindromo rizikos veiksniai, bet jie gali būti ir šio sindromo pasekmè.

\section{Literatūra}

1. Defrees DN, Bailey J. Irritable Bowel Syndrome: Epidemiology, Pathophysiology, Diagnosis, and Treatment. Prim Care 2017;44(4):655-71.

https://doi.org/10.1016/j.pop.2017.07.009

2. Holtmann GJ, Ford AC, Talley NJ. Pathophysiology of irritable bowel syndrome. Lancet Gastroenterol Hepatol 2016;1(2):13346.

https://doi.org/10.1016/S2468-1253(16)30023-1

3. Radovanovic-Dinic B, Tesic-Rajkovic S, Grgov S, Petrovic G, Zivkovic V. Irritable bowel syndrome - from etiopathogenesis to therapy. Biomed Pap Med Fac Univ Palacky Olomouc Czech Repub 2018;162(1):1-9.

https://doi.org/10.5507/bp.2017.057

4. Ford AC, Sperber AD, Corsetti M, Camilleri M. Irritable bowel syndrome. Lancet 2020;396(10263):1675-88.

https://doi.org/10.1016/S0140-6736(20)31548-8

5. Creed F. Review article: the incidence and risk factors for irritable bowel syndrome in population-based studies. Alimentary Pharmacology \& Therapeutics 2019;50(5):507-16.

https://doi.org/10.1111/apt.15396

6. Black CJ, Ford AC. Global burden of irritable bowel syndrome: trends, predictions and risk factors. Nat Rev Gastroenterol Hepatol 2020;17(8):473-86.

https://doi.org/10.1038/s41575-020-0286-8

7. Barbalho SM, Goulart R de A, Araújo AC, Guiguer ÉL, Bechara MD. Irritable bowel syndrome: a review of the general aspects and the potential role of vitamin D. Expert Rev Gastroenterol Hepatol 2019;13(4):345-59.

https://doi.org/10.1080/17474124.2019.1570137

\section{IRRITABLE BOWEL SYNDROME: RISK FACTORS}

\section{A. Norbutaitè}

Keywords: irritable bowel syndrome, IBS, risk factors.

Summary

Irritable bowel syndrome (IBS) is a functional gastrointestinal disorder characterized by chronic, recurrent abdominal pain, discomfort and altered bowel movements that occur in the absence of other organic diseases of the digestive system. The main risk factors for IBS are female gender, younger age, genetic predisposition, dietary habits, history of gastroenteritis and altered microbiota. Stress, anxiety and depression are not only risk factors of IBS, but they may also develop as a consequence. The aim of this study was to analyze and summarize the scientific data on the risk factors of IBS.

Correspondence to: agnenorb@gmail.com

Gauta 2021-05-25 